\title{
Why are Arctic ground squirrels more stressed in the boreal forest than in alpine meadows? ${ }^{1}$
}

\author{
David S. HIK ${ }^{2}$,Carolyn J.McCOLL\& RudyBOONSTRA ${ }^{3}$, Division of Life Sciences, University of Toronto \\ at Scarborough, 1265 Military Trail, Scarborough, Ontario M1C 1A4, Canada, e-mail: boonstra@ scar.utoronto.ca
}

\begin{abstract}
Arctic ground squirrels (Spermophilus parryii plesius Richardson) in the southeastern Yukon live in both boreal forest and alpine tundra habitats. We live-trapped young male and female squirrels in both habitat types and subjected them to a standardized hormonal-challenge protocol to assess the responsiveness of their hypothalamic-pituitary-adrenal axis. Alpine squirrels had levels of free cortisol at the baseline (initial) bleed following their removal from traps that were 3 times higher in males and 5 times higher in females compared with boreal forest squirrels. Females, but not males, from the boreal forest were dexamethasone resistant, while neither sex from the alpine habitat was resistant. Free cortisol in alpine squirrels also responded more dramatically after the injection of adrenocorticotropic hormone. Corticosteroid-binding globulin levels were significantly lower in forest than alpine squirrels and these levels were not markedly affected by the challenge protocol. Glucose levels were significantly higher in boreal than alpine squirrels and the pattern differed between the two sites in response to the protocol. Hematocrits were significantly higher in alpine squirrels. Collectively, this evidence suggests that Arctic ground squirrels were more chronically stressed in the boreal forest than in the alpine meadows. The most likely explanation for our results is higher predation risk in the forest compared with alpine meadows, as forage availability and population density were not significantly different between the two habitats.
\end{abstract}

Keywords: Arctic ground squirrels, hypothalamic-pituitary-adrenal axis, predation risk, stress, sublethal effects.

Résumé : Dans le sud du Yukon, les spermophiles arctiques (Spermophilus parryii plesius Richardson) occupent deux types d'habitat, soit la forêt boréale et la toundra alpine. Nous avons piégé des jeunes mâles et femelles de l'espèce dans chacun des types d'habitat et les avons soumis à un protocole standardisé de réponse hormonale pour évaluer la réactivité de leur axe hypothalamo-hypophyso-adrénalien. Le niveau de cortisol libre initial, mesuré au moment où les animaux étaient retirés des pièges, s'est révélé 3 fois plus élevé chez les mâles et 5 fois plus élevé chez les femelles de la toundra alpine que chez les spermophiles de la forêt boréale. Les femelles spermophiles de la forêt boréale, mais non les mâles, étaient résistantes à la dexaméthasone, alors que ni les mâles ni les femelles de la toundra alpine ne l'étaient. Le cortisol libre réagissait aussi plus fortement chez les spermophiles alpins après injection d'hormone adrénocorticotropique. Les niveaux initiaux de globuline liant les corticostéroïdes étaient significativement plus bas chez les spermophiles forestiers qu'alpins et ces niveaux n'ont pas été affectés significativement par le protocole expérimental. La glycémie était significativement plus élevée chez les spermophiles forestiers que chez ceux de la toundra alpine et le schéma de réponse au protocole différait selon l'habitat. L'hématocrite était significativement plus élevée chez les spermophiles de la toundra alpine. Pris dans leur ensemble, ces résultats suggèrent que les spermophiles arctiques vivant dans la forêt boréale sont davantage sujets au stress chronique que ne le sont leurs conspécifiques de la toundra alpine. La disponibilité de nourriture et la densité des populations de spermonphiles n'étant pas significativement différentes entre les deux habitats, l'explication la plus plausible de nos résultats est le risque de prédation plus élevé dans la forêt que dans la toundra alpine.

Mots-clés : spermophiles arctiques, axe hypothalamo-hypophyso-adrénalien, risque de prédation, stress, effets sublétaux.

\section{Introduction}

Many factors may influence stress responses in wild populations including social interactions mediated by population density, sex ratio, or mating system; availability and quality of food resources; habitat availability; disease and parasitism; environmental conditions; competition; and risk of predation. Isolating the factors responsible for inducing acute or longer-term chronic stress in populations requires considerable knowledge about which factors may play a role in limiting or regulating a population, particularly if comparisons between different sites are to be made. Recent reviews have indicated both the necessity and difficulty of examining effects of stress on individuals in field populations of plants and animals (Parker et al., 1999).

\footnotetext{
${ }^{1}$ Rec. 2000-08-17; acc. 2001-05-16.

2Present address: Department of Biological Sciences, University of Alberta, Edmonton, Alberta T6G 2E9, Canada, e-mail: dhik@ualberta.ca

${ }^{3}$ Author for correspondence.
}

In the boreal forest, Arctic ground squirrel populations show cyclic fluctuations positively correlated with the population cycle of the snowshoe hare (Lepus americanus) (Byrom et al., 2000; Hubbs \& Boonstra 1997; Karels et al., 2000). When hare populations decline because of intense predation pressure (Krebs et al., 1995), squirrel populations decline in tandem with them. Hubbs and Boonstra (1997) found that food and predation interacted to limit squirrel populations in the boreal forest but that predation became increasingly important when hares declined and predators switched to squirrels as an alternative food source. Much of the boreal forest habitat is suboptimal during periods of intense predation and only those burrows in open, exposed areas with high visibility continue to have squirrels living in them during this period (Karels \& Boonstra, 1999). In contrast, in tundra or alpine habitats, populations appear to be more stable (Carl, 1971; Green, 1977; Batzli \& Sobaski, 1980). In alpine communities, ground squirrel populations 
may be limited by food, spacing behaviour (population density), exposure, and burrow availability (Carl, 1971; Green, 1977), but predators are considered to be relatively unimportant (Carl, 1971). Thus, if predation plays a greater role in the lives of squirrels living in the boreal forest than in those living in alpine tundra regions, squirrels in boreal forest habitats may be more chronically stressed owing to higher exposure to continuous predation risk than those in alpine tundra habitats.

Predators may have both direct and indirect effects on prey population dynamics. The direct effects on prey populations involve the death of individuals (Boutin, 1995; Sinclair \& Pech, 1996), whereas the indirect effects involve changes in behaviour, foraging patterns, and reproduction of prey species (Lima \& Dill, 1990; Hik, 1995; Lima, 1998). Rates of predation may vary both spatially and temporally and thus the role of predation as a regulatory factor in population dynamics may range from insignificant to preeminent (Andrewartha \& Birch, 1954; Murdoch, 1994; Sinclair \& Pech, 1996; Krebs et al., 1998).

Squirrels are known to be extremely sensitive to predation risk, modifying their behaviour both in response to direct evidence of predator presence (visual, olfactory, auditory, and tactile stimuli coming from predators) and to indirect evidence which correspond to the increased likelihood of encountering predators (e.g., increased foraging distance from burrows or trees or increased visual obstructions) (Arenz \& Leger, 1997; Thorson et al., 1998). Ground squirrels are line-of-sight animals, engaging in vigilance behaviour by utilizing their burrow mounds and other high points to reduce the risk of predation (MacHutchon \& Harestad, 1990; Hubbs, Karels \& Byrom, 1996) and being exposed to higher predation risk when visual obstructions (shrubs, trees) are present (Schooley, Sharpe \& Van Horne, 1996). Large scale ecosystem studies into the vertebrate community in the boreal forest in the southern Yukon (Boutin et al., 1995; Krebs et al., 1995) and simultaneous smaller scale studies in adjacent alpine tundra areas allowed us to investigate whether stress physiology of Arctic ground squirrels differed in habitats with very different predator densities.

When challenged by an acute stressor, the mammalian body responds sequentially in two ways: a rapid, shortterm immediate response involving sympathetic release of epinephrine from the adrenal medulla and a delayed, longer-term response involving the hypothalamic-pituitaryadrenocortical (HPA) feedback system. We focus on the latter one. This response can be triggered by both an immediate threat to survival, such as an attack by a predator, or by the mere expectation that a threat is about to occur (Mason, 1968; Levine, Coe \& Wiener, 1989) The rapid activation of epinephrine from the adrenal medulla and then of the HPA axis maximizes the chances of survival by preparing the body for either "fight or flight" (Lee \& McDonald, 1985; Sapolsky, 1992). The response results in the mobilization of glucose, the curtailment of unessential anabolism, the blunting of pain perception, the sharpening of cognition, the increase of cardiovascular and pulmonary tone, and the inhibition of the functions not needed to pro- mote survival in the immediate future (e.g., the immune and inflammatory responses, reproduction, etc.) (Sapolsky, 1992). However, its role is to deal with acute, not chronic, environmental challenges (Munck, Guyre \& Holbrook, 1984) and if activated chronically, it can be deleterious resulting in inhibition of growth, impaired disease resistance, infertility, and hypertension.

We tested the hypothesis that Arctic ground squirrels living in the boreal forest are more chronically stressed than those living in alpine habitats, primarily as a result of differences in predation risk between these two areas. We assessed the ability of animals living in these two areas to handle a standardized stressor by means of a hormonalchallenge protocol. This protocol allowed us to get an integrated picture of a squirrel's ability to respond to stress while overriding the immediate stress response it was experiencing because of the effects of capture and handling. This hormonal-challenge protocol involved two steps: the dexamethasone suppression test (Kalin et al., 1981) followed by the adrenocorticotropic hormone (ACTH) stimulation test. The dexamethasone suppression test is a method to assess whether the brain is registering glucocorticoid levels correctly (dexamethasone is a potent artificial glucocorticoid) and making the necessary negative feedback adjustment by reducing ACTH and cortisol production. The ACTH stimulation test is a method to assess the responsiveness of adrenals directly. This protocol, or modifications of it, has been successfully applied in studies on stress in a wide variety of species in field studies (e.g., deer: Smith \& Bubenik, 1990; sparrows: Astheimer et al., 1994; snowshoe hares: Boonstra et al., 1998; red squirrels: Boonstra \& McColl, 2000; Arctic ground squirrels: Boonstra, McColl $\&$ Karels 2001). We assessed the stress response of juveniles in late summer as they were approaching their adult body weight.

We make the following specific predictions in comparing alpine and boreal forest squirrels.

i) Chronic stress will result in squirrels with an altered cortisol responsiveness to the challenge tests relative to normal squirrels. In some species, chronic stress causes a hypertrophy of the adrenals resulting in an exaggerated response when stressed (see Miller \& Tyrrell, 1995, and Boonstra et al., 1998 for citations), whereas in other species the response is attenuated (Harlow et al., 1992). Since dexamethasone resistance (i.e., when dexamethasone is given, endogenous cortisol will not fall as rapidly in resistant animals as in normal ones) is characteristic of chronically stressed animals (Sapolsky, 1983; McDonald et al., 1986; Bradley, 1990) and we expect to find this if squirrels are chronically stressed.

ii) Concentrations of the carrier protein for cortisol, corticosteroid-binding globulin (CBG), will decline if animals are chronically stressed. The bioavailability of circulating cortisol for target tissues is mediated by $\mathrm{CBG}$ and, when bound to CBG, cortisol is biologically inactive (Siiteri et al., 1982; Rosner, 1990). Typically when an animal has not been stressed, $90-95 \%$ of plasma cortisol is bound to CBG. However, chronic stress is known to cause a reduction in CBG levels (Dallman et al., 1990; Armario et al., 1994; 
Fleshner et al., 1995) and thus decreased capacity of plasma to bind cortisol. Therefore, chronically stressed squirrels should have decreased CBG levels.

iii) Glucose is the critical fuel that sustains the energy demands of the body. Chronic stress will cause excessive levels of cortisol which will increase hepatic production and storage of glucose as glycogen by enhancing the liver's capacity for gluconeogenesis (Miller \& Tyrrell, 1995). Gluconeogenesis comes at the expense of peripheral tissues by decreasing their glucose uptake and utilization, by the release of gluconeogenic substrate from peripheral tissues, by increasing protein breakdown in several tissues such as muscle, adipose, and lymphoid, and by decreasing protein synthesis. Thus, if animals are chronically stressed, they should have a greater ability to mobilize glucose from larger liver stores.

iv) Packed red blood cell volume (hematocrit) is an integrative index of body condition in which higher values have been linked to better condition and access to better quality forage (Franzmann \& LeResche, 1978; Lochmiller et al., 1986; Hellgren, Rogers \& Seal, 1993; Boonstra et al., 1998). Thus if animals are chronically stressed and in poorer condition, we expect their hematocrits to be lower.

v) Chronic stress should produce higher levels of free cortisol which should act as an immunosuppressant (Munck, Guyre \& Holbrook, 1984; Keller, Schleifer \& Stein, 1984; Kelley, 1985), and we predict that this should result in lower levels of white blood cells involved in the immune response.

\section{Material and methods}

\section{STUDY SPECIES}

The Arctic ground squirrel is North America's northernmost ground squirrel species, and is found throughout the tundra and alpine areas of mainland Canada, into the boreal forests of northwestern Canada, and throughout Alaska (Banfield, 1974). They are obligate hibernators, emerging above ground from a seven- to eight-month hibernation in early to mid-April, with males appearing about one to two weeks before females (Carl, 1971; Lacey, 1991). Mating occurs within several days of female emergence and is generally highly synchronous. Yearlings are reproductively mature and thus the entire population breeds each year. Litters are born 25 days later, appear above ground in late June, and are weaned one week later (Lacey, 1991). Juvenile squirrels grow extremely rapidly during their first season, approaching adult body weight prior to hibernation, as they must both acquire fat reserves to sustain them during their winter hibernation and be prepared to reproduce on emergence the next spring (Karels et al., 2000). Most juveniles males disperse in mid-July, whereas juvenile females are philopatric and remain near their mothers (Byrom et al., 2000). Adult females usually enter hibernation in late July to mid-August, followed by juvenile females and adult males in late August-September, and finally by juvenile males as late as in early October (McLean, 1981).

\section{STUDY SITES: CLIMATE, PREDATORS AND VEGETATION}

\section{BOREAL FOREST SITE}

The boreal forest squirrels were a random sample of juvenile squirrels (10 males and 10 females) trapped between 25 July and 4 August, 1995, from a small, open meadow valley along the Alaska highway near Kluane Lake, Yukon Territory, Canada (60 57' N, 138 $12^{\circ}$ 'w, $900 \mathrm{~m}$ elevation). The boreal forest surrounding this site is heterogeneous, and is dominated by white spruce forests (Picea glauca) ( $43 \%$ coverage) with an understory of willow (Salix spp.) and birch (Betula glandulosa), willow shrub thickets $(45 \%)$, grass meadows $(8 \%)$ and aspen poplar stands (Populus tremuloides) (5\%), based on airphoto analysis (Krebs et al., 2001). The climate is cold continental with the growing season extending from mid-May through midAugust and snow cover occurring from October through early May. The Kluane Lake area experiences a mean July temperature of approximately $11^{\circ} \mathrm{C}$. This forest has been the site of large-scale experiments on the dynamics of the boreal forest and investigations into the boreal forest ecosystem (Boutin et al., 1995; Krebs et al., 1995; 2001).

The main predators of Arctic ground squirrels in this boreal forest are coyote (Canis latrans), lynx (Lynx canadensis), great horned owl (Bubo virginianus), and goshawk (Accipiter gentilis) (Doyle \& Smith, 1994; O'Donoghue et al., 1998). In 1995, the numbers of all of these predators were low as a consequence of the snowshoe hare decline from 1991 to 1993 (Boutin et al., 1995; Boonstra et al., 1998). Other potential predators of Arctic ground squirrels include grizzly bear (Ursus arctos), weasel (Mustela nivalis and M. erminea), wolverine (Gulo gulo), wolf (Canis lupus), red-tailed hawk (Bubo jamaicensis), golden eagle (Aquila chrysaetos), bald eagle (Haliaeetus leucocephalus), northern harrier (Circus cyaneus) and rough-legged hawk (Buteo lagopus); however, all of these predators were relatively few in number. An index of predator numbers and activity was based on observations of all predators made by field researchers using standard techniques (Hochachka et al., 2000) between 1 June and 31 August, 1995.

Summer food availability for ground squirrels was estimated at two sites using a clip plot technique during late July at the time of maximum above-ground biomass, between 1989 and 1991, near the areas where the ground squirrels were captured. We do not have estimates for 1995 and use data from these three years as an indication of primary production in the boreal forest. Each year the total above-ground biomass of graminoids, forbs, legumes (primarily Lupinus arcticus), shrubs, and prostrate subshrub vegetation in ninety $30 \mathrm{~cm} \times 30 \mathrm{~cm}$ plots was clipped at ground level, sorted by species, dried at $60^{\circ} \mathrm{C}$, and weighed.

\section{ALPINE MEADOW SITE}

The alpine meadow squirrels were a random sample of juvenile squirrels (five males and eight females) trapped between 26 July and 2 August, 1996. This site (Pika Creek) was in an alpine meadow valley $\left(61^{\circ} 20^{\prime} \mathrm{N}, 138^{\circ} 25^{\prime} \mathrm{w}\right)$ in a tributary of the Swanson Creek drainage system, approximately $20 \mathrm{~km}$ north of the above boreal forest study site at Kluane Lake. The alpine tundra site lies above the tree line $(\sim 1200 \mathrm{~m})$ with east- and west-facing slopes rising from an elevation of 1700 to $2200 \mathrm{~m}$ above sea level. The valley is comprised of alpine meadows fragmented by large (up to $4 \mathrm{ha}$ ) boulderfields. Vegetation cover is primarily a lichenheath complex, dominated by willow (Salix spp), Carex 
spp., Dryas octopetala, and Cassiope tetragona (McIntire, 1999). Across the study site boulderfields cover approximately $36 \%$ of the area, vascular plants $27 \%$, and the remainder is moss, lichen or bare ground. The snow-free growing season is approximately 70 days, with mean July temperatures of $7^{\circ} \mathrm{C}$ and the first snowfall typically occurring by the end of the third week of August (D.S. Hik, unpubl. data).

Many predators of Arctic ground squirrels at the alpine site are similar to those in the boreal forest. An index of predator abundance was based on field observations made from 15 June to 20 August 1996 with methods similar to those used in the boreal forest.

Food availability was estimated at two sites (meadow and talus) in the study area using a clipplot technique. The total amount of above-ground graminoid, herbaceous and woody subshrub vegetation in forty $10 \mathrm{~cm} \times 10 \mathrm{~cm}$ plots was clipped at ground level, sorted by species, dried at $60^{\circ} \mathrm{C}$, and weighed. Clipping was conducted on 15 August, 1996, during the time of peak above-ground biomass.

\section{POPULATION ESTIMATION}

In the boreal forest, traps were prebaited with peanut butter at least twice within the three days prior to census trapping, which was conducted throughout the summer of 1995. Traps were set at 07:00 and checked at 1.5-hour intervals three times each day. This was repeated for three to four days or until the standard error of the estimate was within $5 \%$ of the estimated population size calculated by the appropriate model selected by the program CAPTURE. The three captures per day were pooled to represent one trapping period. This increased the sample size per trapping period, which reduced the standard error, by reducing the number of model parameters that had to be estimated (Menkens \& Anderson, 1988).

In the alpine habitat, traps were prebaited with peanut butter placed at burrow entrances, on runways (frequently used paths), and in talus. Squirrels were intensively trapped on two areas (9 and 3.5 ha) throughout their active period, during three sessions (19-24 July, 31 July to 2 August, and 11-18 August, 1996). The density estimate was conservatively calculated as the total number of squirrels trapped in at least two of the three trapping sessions. Animals captured in two or more trapping sessions were considered to be residents of the study area, and provided an estimate of the minimum number of animals present. Since the trappability of squirrels is very high (Hubbs \& Boonstra, 1997), the enumerated values of the populations in the alpine were probably close to the actual values.

\section{EXPERIMENTAL ANIMALS}

Based on the results of the population trapping regime above, animals were targeted for experimental stress challenge studies. Traps were placed at the entrance to these individuals burrows between 08:00 and 09:30 and were checked hourly. As soon as animals were trapped, they were brought to a centralized shelter prior to being anesthetized. In the alpine habitat, animals were in the traps for no more than about 15 minutes before being collected, and in the boreal forest site, animals were in the traps for no more than 60 minutes. The challenge experiment was performed after a habituation period of about 1.5 hours to standardize the trap experience among animals; all were covered with burlap to minimize visual contact with us and with other animals.

\section{Hormonal Challenge Protocol}

All animals were anesthetized prior to the collection of each blood samples with the inhalant anesthetic Metofane (methoxyflurane) at an approximate concentration of 3\% using the bell-jar technique (McColl \& Boonstra, 1999). Animals were anesthetized within 30-90 seconds of entering the device and blood samples were collected within 1 minute thereafter. To increase the vapor pressure of the Metofane and to decrease the length of time required to anesthetize the squirrels, the induction chambers at the boreal forest site were 'warmed' in the sun on clear days and by body heat on overcast days; in the alpine, the induction chambers were warmed over a portable stove. If this was not done, the time required for induction would have been $>10$ minutes. Animals regained consciousness rapidly following removal from the induction chamber. The above anesthetic and bleeding procedure follows the Canadian Council of Animal Care guidelines and was approved under a University of Toronto Animal Use Protocol.

Each squirrel was bled five times by suborbital sinus puncture. Blood from the first sample (called the BASE bleed, $\sim 500 \mu \mathrm{L}$ ) was used to obtain baseline estimates of blood parameters. Although these values are not true baseline levels, as the squirrels had already responded to the stress of capture and handling, these values provide baseline levels in the context of the experimental challenge described below. Immediately following the collection of the baseline sample, animals were injected with $0.4 \mathrm{mg} \mathrm{kg}^{-1}$ dexamethasone sodium phosphate (Sabex, Montréal, Canada) by cardiac puncture as recommended by B. Barnes (University of Alaska, Fairbanks). The second blood sample (called the DEX bleed, $300 \mu \mathrm{L}$ ) was collected 2 hours after the dexamethasone injection and was immediately followed by an intramuscular injection into the thigh of $4 \mathrm{IU} \mathrm{kg}^{-1}$ of synthetic ACTH (Synacthen Depot, CIBA, Ontario, Canada). Subsequent blood samples were collected at 30, 60, and 120 minutes post-ACTH injection (called the P30, P60, and P120 bleeds, respectively, and all $300 \mu \mathrm{L}$ ).

\section{HEMATOLOGY}

Blood samples were collected in heparinized $75 \mu \mathrm{L}$ microhematocrit tubes (Red-Tips: Fisher Scientific Co.) and were allowed to flow into $0.5 \mathrm{~mL}$ Eppendorf tubes. Blood samples were stored on ice in the field. Measurement of glucose concentrations was usually completed within 5 minutes of collection and always within 15 minutes. Hematology was conducted only on the first bleed of each animal, except for glucose concentrations which were measured for all samples. Glucose concentrations $\left(\mathrm{mg} \mathrm{dL}^{-1}\right)$ were measured after each bleed by glucose oxidase/peroxidase reaction (Accu-chek III, Mannheim-Boehringer, Mannheim, Germany). The accuracy of the device was compared with standard control solutions and the values were within $20 \%$ of the value for the low control solution $\left(51 \mathrm{mg} \mathrm{dL}^{-1}\right)$ and $10 \%$ for the high control solution (292 $\left.\mathrm{mg} \mathrm{dL}^{-1}\right)$.

Hematocrit was measured as the percent packed red blood cell volume in $75 \mu \mathrm{L}$ heparinized microhematocrit 
tubes sealed with Critoseal. Hematocrit was measured on two samples per squirrel after a 5-minute centrifugation at $13460 \mathrm{~g}$ on an IEC Micro-Hematocrit Centrifuge, Model MB upon return to the field stations. Two blood smears for identification and quantification of white blood cell type were made from the baseline sample of each animal. Blood samples were vortexed prior to the preparation of blood smears to ensure an even distribution of cells. The smears were fixed and stained with a modified Wright Stain technique using Diff-Quik (Baxter Health Care Corp., Florida, U.S.A.). Differential white blood cell counts were based on counts of 100 leucocytes and total number of leucocytes were calculated per field of view (Cook, pers. comm.). The remaining blood was centrifuged at $8800 \mathrm{~g}$ for 8 minutes in an Eppendorf Micro Centrifuge. The separated plasma was frozen and stored at $-20^{\circ} \mathrm{C}$ until transported to Toronto, where it was stored at $-70^{\circ} \mathrm{C}$ until analysis.

\section{CORTISOL ASSAY}

Total plasma cortisol was measured by the radioimmunoassay method of Boonstra \& Singleton (1993). Antibody A-155 was obtained from Western Chemical (Fort Collins, Colorado) and showed the following crossreactivities: corticosterone, $1.4 \%$; progesterone, $1.0 \%$; and estradiol, estriol, and estrone, $<0.1 \%$. Blank values of solvents were run with each assay and did not differ significantly from zero. To limit within treatment variation, all samples of a particular sex from one site were run in one assay. The intra- and interassay coefficients of variation for cortisol were $6 \%$ and $11 \%$, respectively. The sensitivity of the cortisol assay was $10 \mathrm{pg} / 10 \mu \mathrm{L}$ plasma.

Critical to understanding the potential impact of changing cortisol levels is knowing how much cortisol is actually free and not bound to its main carrier protein, corticosteroid binding globulin (CBG). Plasma corticosteroid-binding globulin $(\mathrm{CBG})$ was measured as the maximum corticosteroid binding capacity (MCBC) using $\left[1,2,6,7-{ }^{3} \mathrm{H}\right]$ cortisol (Amersham), diluted in cold cortisol to known specific activity 5 - to 20-fold in excess of the expected capacity (see McDonald et al., 1981 for details of method). We allowed for the contribution of the endogenous cortisol in the sample. The high-affinity fraction in a $10 \mu \mathrm{L}$ sample of plasma, diluted in $0.5 \mathrm{~mL}$ phosphate buffer, was measured by liquid scintillation after separation from the free- and albumin-bound fractions with dextran-coated charcoal. The high-affinity-bound cortisol was then calculated knowing the specific activity and the radioactivity in the bound fraction. To calculate the concentrations of free cortisol, we used the calculation procedures outlined in Boonstra et al. (1998). Ground squirrels were calculated to have an average value of $2.54 \mathrm{~g}$ albumin per $100 \mathrm{~mL}$ plasma. Although albumin levels can vary owing to such factors as nutrition and stress (Peters, 1996), it has low affinity for cortisol relative to CBG (the latter binding cortisol by approximately 6000 times that of albumin; e.g., Sandberg \& Slaunwhite, 1959), and thus slight variation in albumin levels should not have major influences on the amount of cortisol that is free (Tait \& Burstein, 1994). The ratio of albumin bound to free cortisol in a $1 \%$ solution is 0.19 and the $\mathrm{CBG}$-binding constant for Arctic ground squirrels was calculated to be $4.505 \times 10^{7} \mathrm{M}^{-1}$.

\section{STATISTICAL ANALYSES}

We analyzed males and females separately, as previous analyses indicated that the sexes differ markedly in their adrenal responses (McColl, 1998). Data are expressed as means \pm SE. We used Cochran's test (Winer, 1971) as recommended by Day \& Quinn (1989) to test for homogeneity of variance. The hormone and glucose data did not meet the assumption of homogeneous variances, and we used the $\log (\mathrm{x} \pm 1)$ transformation to make the variances homogeneous. All ANOVAs were performed using SuperANOVA (Gagnon et al., 1990). A repeated measures ANOVA was carried out on squirrels that were hormonally challenged. In a repeated-measures design, the values recorded from the same animal will be correlated with each other and thus are not independent as assumed by ANOVA. To compensate for this, we used the conservative Greenhouse-Geisser epsilon to adjust the degrees of freedom before calculating the probabilities as recommended by Keppel (1982). We used the Tukey-Kramer multiple comparison post-hoc test to examine the significance of main effects.

Although we challenged five males in the alpine habitat, we present the data for only four of them. One individual was excluded from the analysis as it was a marked outlier (glucose levels and free cortisol levels at the P120 dropped to $27 \%$ and $14 \%$, respectively, of the other four individuals, even though MCBC levels were normal). We do not know why this animal responded so differently, and this response was not observed in any of the 190 other animals tested with a similar protocol during the course of these and other experiments (McColl, 1998).

\section{Results}

\section{POPULATION DENSITY}

The ground squirrel density in the boreal forest was 2.7 squirrels/ha. In the alpine, a total of 52 animals were captured or recaptured during the three sample periods and estimated that the minimum number alive ranged from 1.4 animals/ha in the boulderfields to 3.7 animals/ha in continuous alpine meadows. Thus densities were largely comparable in the alpine and boreal forest sites.

\section{PREDATORS}

In the boreal forest, a total of 5430 person hours of observation resulted in 414 sightings of potential predators of Arctic ground squirrels (C. J. Krebs et al., unpubl. data), or approximately 0.76 sightings/100 hours. The most frequently observed predators were red-tailed hawk (0.22 100 hour $\left.^{-1}\right)$, kestrel (Falco sparverius) (0.15 100 hour $\left.^{-1}\right)$, and goshawk $\left(0.13100\right.$ hour $\left.^{-1}\right)$. More extensive counts of tracks of lynx and coyote in winter recorded fewer than one track per $100 \mathrm{~km}$ of transect, providing additional support for the low numbers of animals observed in summer (O'Donoghue et al., 1998). Similarly, in 1995 there were fewer than 10 pairs of great horned owls and three pairs of goshawks per $100 \mathrm{~km}^{2}$ in the study area (Krebs et al., 2001).

In the alpine tundra, predators were observed only onethird as frequently as in the boreal forest. A total of 1600 person hours of observation provided 38 sightings of predators (mean of 0.24100 hour $\left.^{-1}\right)$, with kestrel (0.13/100 hour) and ermine (0.06 100 hour $\left.^{-1}\right)$ being most commonly record- 
ed. Ermine (about $80 \mathrm{~g}$ body mass) are relatively common but most likely prey mainly on smaller voles and collared pikas (Ochotona collaris). Rough-legged hawks, kestrels, and golden eagles have been observed in the area, but infrequently (less than 6 sightings). Grizzly bear, wolf and fox (Vulpes vulpes) were also observed on one occasion each during the summer of 1996. There are few signs of grizzly bear diggings on ground squirrel burrows in the alpine.

\section{VEGETATION BIOMASS}

On a biomass basis, the dominant species of graminoid, herbaceous and woody forage plants in the boreal forest were Arctostaphylos uva-ursi, A. rubra, leaves of Salix spp. and Betula, Carex spp., Festuca altaica, and Lupinus arcticus (Figure 1a). The total biomass of available forage (dry weight) was similar in all three years and ranged from 35 to $70 \mathrm{~g} \mathrm{~m}^{-2}$ (SE approximately $11-15 \%$ of the mean for each sample; $p>0.15$ ) across the two sites sampled. In the alpine meadows, the dominant species were Dryas octopetala, Carex spp., and Salix reticulata (Figure 1b). The total biomass of available forage was $42 \pm 5 \mathrm{~g} \mathrm{~m}^{-2}$ adjacent to boulderfields (talus habitat), and $71 \pm 6 \mathrm{~g} \mathrm{~m}^{-2}$ in the surrounding meadows which were used most extensively by squirrels (van Dishoeck, 1997). Thus, although there were differences in species composition, peak-season above-ground biomass availability values were broadly comparable in both alpine and boreal forest sites.

\section{SQUIRREL BODY MASS}

For each sex, we carried out a one-way ANOVA on mass and found alpine males to be about $70 \mathrm{~g}$ heavier than boreal forest males (alpine site: $N=4,462.5 \pm 26.8 \mathrm{~g}$; boreal site: $N=10,390.5 \pm 20.0 \mathrm{~g})\left(F_{1,12}=4.0, P=0.07\right)$

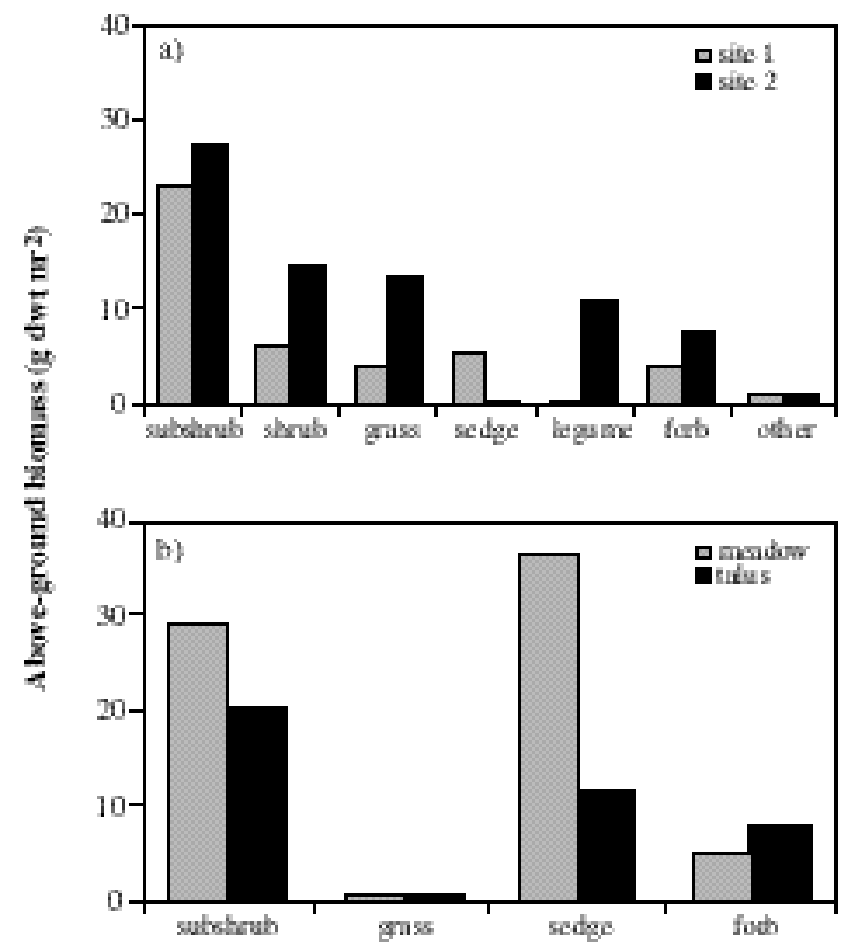

FIGURE 1. Above-ground peak season live biomass of vegetation potentially available to squirrels in a) boreal forest (mean values over three years at two sites), and b) alpine tundra habitats near Kluane Lake, Yukon. but females to be similar at both sites (alpine site: $N=8$, $412.9 \pm 7.6$; boreal site: $N=10,432.5 \pm 18.2)\left(F_{1,16}=0.8\right.$, $P=0.37)$.

\section{PlASMA CORTISOL LEVELS}

To assess how free cortisol levels changed, we present three analyses: first, we analyzed how BASE levels differed between the two sites, since these would represent the responses of the squirrels to trapping and handling; second, we present the overall average response of the squirrels to the challenge test; and third, we present the within-subject effects showing how the levels varied over time as a function of the injections. Free cortisol levels at BASE were significantly higher in both sexes in alpine squirrels than in boreal forest squirrels (males: $F_{1,12}=14.4, P=0.003$; females: $\left.F_{1,16}=53.5, P<0.0001\right)$. In males, levels were three times higher (alpine: $124.7 \mathrm{nM} \pm 38.7$; boreal: $41.5 \pm 2.9)$ and in females, levels were five times higher (alpine: $219.0 \mathrm{nM} \pm 30.8$; boreal: $44.1 \pm 5.3$ ). MCBC levels at BASE were similar between the two sites (males: $F_{1,12}=0.3$; females: $F_{1,12}=1.2$ ) (Figure 2 ).

The repeated-measures ANOVA indicated that, averaged over the entire experiment (after the removal of variance owing to within-subject effects), free cortisol was significantly higher in both males and females from the alpine site than from those in the boreal forest site (Figure 2, Table I). In males, alpine squirrels had levels 2.9 times higher than those of boreal forest animals and in females, alpine squirrels had levels 3.6 times higher than those of boreal forest squirrels. However, these differences were not the result of different MCBC levels, which were similar between the sites within the sexes (Table I).

The within-subjects effects examining the responses to the injections over time were significantly different between the sites in males and females for free cortisol, but these effects are complicated by significant interaction effects (Table II). Males from both sites responded dramatically to the DEX injection, with free cortisol levels dropping to about the same level $(<2 \mathrm{nM})$. Following the ACTH injection, males from the alpine showed a much greater response than those from the boreal forest. Within 30 minutes (P30), free cortisol levels in males from the alpine were $65 \%$ higher than those at BASE, whereas levels in males from the boreal forest were only $16 \%$ higher. Thereafter, levels in alpine males fell so that by P120, they were $25 \%$ higher than those at BASE, whereas levels in boreal forest males were $71 \%$ higher. This difference in response to the ACTH accounts for the significant interaction effect.

The pattern in females mimicked that in males, with some modifications. First, the injection of DEX also resulted in a dramatic decline in free cortisol levels in alpine females (from 219.0 at BASE to $7.08 \mathrm{nM}$ at DEX), but not in boreal forest females (from 44.8 at BASE to $22.27 \mathrm{nM}$ at DEX). Thus, boreal forest females, but not males, showed evidence of dexamethasone resistance. Following the ACTH injection, females from both sites responded, with changes in levels from the alpine being more dramatic (going to $255.70 \mathrm{nM}$ at P30) than those from the boreal forest (going to $67.92 \mathrm{nM}$ ). Thereafter, levels in females from the alpine increased to a peak at P60 and then fell at P120 to levels approximating those at BASE; levels in 

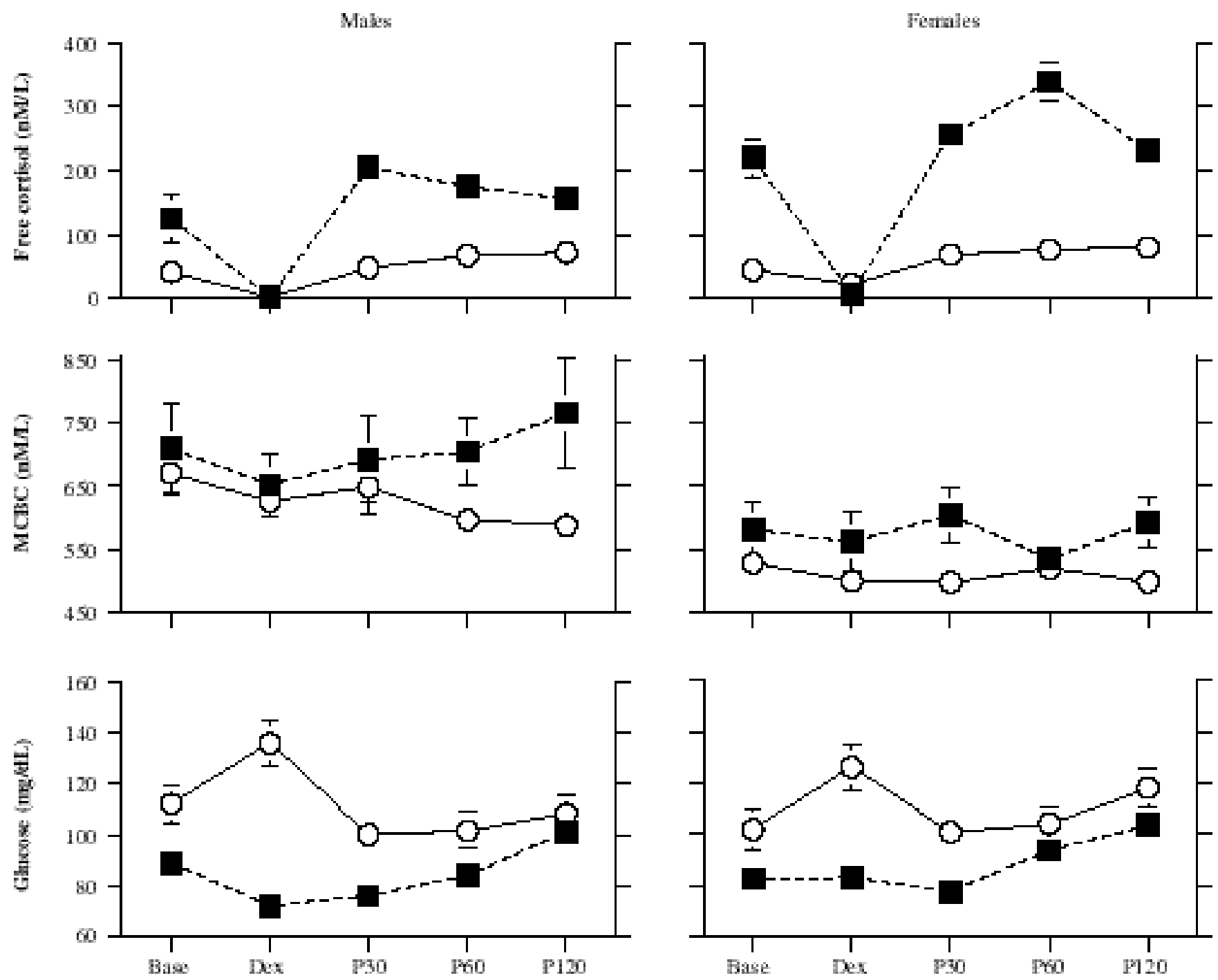

FIGURE 2. Response over time in plasma concentrations (means \pm SE) of free cortisol (F), maximum corticosteroid binding capacity (MCBC), and glucose in juvenile male (left, $N=4$ alpine and 10 boreal) and juvenile female (right, $N=8$ alpine and 10 boreal) Arctic ground squirrels from the alpine ( $)$ and boreal forest $(\mathrm{O})$ near Kluane Lake, Yukon. BASE levels indicate initial values, DEX indicates values 120 minutes after the dexamethasone injection, and P30, P60 and P120 indicate values 30, 60, and 120 minutes after the ACTH injection.

females from the boreal forest increased continually following the ACTH injection, so that by P120 they were almost twice BASE levels. Again, these different patterns in free cortisol levels between the two sites explain the interactions effects.

TABLE I. Summary of the average effect (mean \pm SE) of the hormonal challenge over the entire challenge experiment on juvenile Arctic ground squirrels from two different habitats.

\begin{tabular}{llcc}
\hline \hline & & Alpine & Boreal Forest \\
\hline MALES & & & \\
& Free cortisol $(\mathrm{nM}) * * *$ & $132.2 \pm 18.5$ & $45.9 \pm 4.1$ \\
& MCBC $(\mathrm{nM})$ & $704.8 \pm 28.0$ & $626.1 \pm 13.5$ \\
& Glucose $(\mathrm{mg} / \mathrm{dL}) * *$ & $84.6 \pm 3.1$ & $111.5 \pm 3.7$ \\
FeMALES & & & \\
& Free cortisol $(\mathrm{nM}) * * *$ & $210.1 \pm 20.0$ & $58.1 \pm 4.2$ \\
& MCBC $(\mathrm{nM})$ & $575.0 \pm 17.7$ & $508.8 \pm 10.3$ \\
& Glucose $(\mathrm{mg} / \mathrm{dL}) *$ & $88.0 \pm 2.6$ & $110.0 \pm 3.6$ \\
\hline \hline
\end{tabular}

Treatment effects: $* P<0.01, * * P<0.001, * * * P<0.0001$.
The within-subjects effects examining the MCBC responses to the injections show relatively little change over time (Figure 2, Table II) and there are no significant differences except for an interaction effect in males, with alpine animals showing increasing levels after the ACTH injection and boreal forest males showing decreasing levels. Nevertheless, in both males and females, levels appear higher in alpine than boreal forest squirrels, and the lack of significance may be a sample size problem. To examine whether this was indeed real, we pooled both sexes and carried out a two-way repeated measures ANOVA $($ Sex $\times$ site $)$. Animals from the alpine habitat had significantly higher MCBC levels than those from the boreal forest $\left(F_{1,116}=6.52, P=0.02\right)$; males also had significantly higher levels than females $\left(F_{1,116}=19.55, P<0.0001\right)$ and there were no interaction effects $\left(F_{1,116}=1.56\right)$.

\section{Plasma GLUCOSE LEVELS}

The repeated-measures ANOVA indicated that, averaged over the entire experiment, glucose levels were 
TABLE II. Repeated measures ANOVA testing differences between alpine and boreal forest Arctic ground squirrels in response to the hormonal-challenge protocol. The probability estimates of the within-subject (time) analysis were adjusted using the Greenhouse-Geisser estimate. All absent probability values are nonsignificant, but those just above significance are also given.

\begin{tabular}{|c|c|c|c|c|}
\hline Source & $\mathrm{df}$ & MS & $F$ & $P$ \\
\hline \multicolumn{5}{|l|}{ MALES } \\
\hline \multicolumn{5}{|l|}{ Free cortisol } \\
\hline Treatment & 1 & 2.036 & 86.1 & 0.0001 \\
\hline Subject (group) & 12 & 0.024 & & \\
\hline Time & 4 & 5.639 & 211.6 & 0.0001 \\
\hline Time $\times$ treatment & 4 & 0.104 & 3.9 & 0.03 \\
\hline Error & 48 & 0.027 & & \\
\hline \multicolumn{5}{|l|}{$\mathrm{MCBC}$} \\
\hline Treatment & 1 & 0.035 & 1.8 & \\
\hline Subject (group) & 12 & 0.020 & & \\
\hline Time & 4 & 0.002 & 1.8 & 0.17 \\
\hline Time $\times$ treatment & 4 & 0.004 & 4.7 & 0.007 \\
\hline Error & 48 & 0.001 & & \\
\hline \multicolumn{5}{|l|}{ Glucose } \\
\hline Treatment & 1 & 0.184 & 18.6 & 0.001 \\
\hline Subject (group) & 12 & 0.010 & & \\
\hline Time & 4 & 0.010 & 1.7 & \\
\hline Time $\times$ treatment & 4 & 0.024 & 3.8 & 0.009 \\
\hline Error & 48 & 0.006 & & \\
\hline \multicolumn{5}{|l|}{ FEMALES } \\
\hline \multicolumn{5}{|l|}{ Free cortisol } \\
\hline Treatment & 1 & 3.839 & 91.3 & 0.0001 \\
\hline Subject (group) & 16 & 0.042 & & \\
\hline Time & 4 & 4.600 & 83.0 & 0.0001 \\
\hline Time $\times$ treatment & 4 & 0.736 & 13.3 & 0.0002 \\
\hline Error & 64 & 0.055 & & \\
\hline \multicolumn{5}{|l|}{ MCBC } \\
\hline Treatment & 1 & 0.054 & 3.4 & 0.08 \\
\hline Subject (group) & 16 & 0.016 & & \\
\hline Time & 4 & 0.001 & 0.05 & \\
\hline Time $\times$ treatment & 4 & 0.003 & 1.2 & \\
\hline Error & 64 & 0.003 & & \\
\hline \multicolumn{5}{|l|}{ Glucose } \\
\hline Treatment & 1 & 0.193 & 9.8 & 0.006 \\
\hline Subject (group) & 16 & 0.020 & & \\
\hline Time & 4 & 0.026 & 5.7 & 0.005 \\
\hline Time $\times$ treatment & 4 & 0.013 & 2.9 & 0.03 \\
\hline Error & 64 & 0.005 & & \\
\hline
\end{tabular}

significantly higher (by approximately $25 \%$ ) in boreal forest squirrels than in alpine squirrels for both males and females (Table I, Figure 2) and this difference was already apparent at the BASE bleed. The pattern of change in glucose levels as a function of the injections was remarkably similar in males and females (Figure 2) but differed between the two sites, and hence the significance of the interaction effects (Table II). DEX caused glucose levels to increase in both males and females from the boreal forest (by over $21 \%$ above BASE levels), whereas there was a modest decline in levels in alpine males and no change in alpine females. ACTH caused glucose levels to decline by P30 in both males and females from the boreal forest back to or lower than BASE levels; there was little change in levels of the alpine squirrels. Thereafter, levels in all animals increased until the end of the experiment. Thus, boreal forest squirrels had higher glucose levels than alpine squirrels and responded more dramatically and in a different pattern to the challenge protocol than did those squirrels from the alpine site.

\section{BLOOD PARAMETERS}

Hematocrit at the BASE bleed was significantly higher in both males and females from the alpine habitat than in those from the boreal forest (males: $F_{1,12}=25.9, P=0.0003$; females: $F_{1,16}=32.3, P<0.0001$ ) (Figure 3 ). In both sexes, alpine animals had about $6 \%$ more packed red cell volume in plasma than did boreal forest squirrels (approximately $51 \%$ versus $44 \%$, respectively). In whole blood, there was no difference in males between the two sites in the proportion of each of the white blood cell types present nor in their total concentration (Table III). In the females, there was also no difference in the proportion of white blood cell types present, but alpine animals had significantly more white blood cells per field of view (about two times) than boreal forest animals. Part of our problem in detecting differences between the sites in cell types was low sample size. Eosinophils appeared much lower in both males and females at the alpine than the boreal forest site, so to increase sample size, we pooled the sexes. We then found a significant difference $(P<0.05$, Mann-Whitney test), with about $20 \%$ as many eosinophils in alpine as in boreal forest squirrels (alpine $=0.17 \pm 0.11$ boreal $=0.90 \pm 0.24$ ) . Thus, hematocrit is significantly higher in alpine squirrels than boreal forest squirrels, and (in females but not males), white blood cell concentrations are higher and in both sexes; eosinophils appear lower in alpine squirrels.

\section{Discussion}

Our results indicate that there were profound differences in the stress physiology of Arctic ground squirrels living in alpine tundra from those living in the adjacent boreal forest. Alpine squirrels had levels of free cortisol at the baseline bleed (indicative of the effects of trapping and handling) that were three and five times higher in males and females, respectively, than in boreal forest squirrels (Figure 2). Males from both sites and females from the alpine site showed no evidence of dexamethasone resistance, with

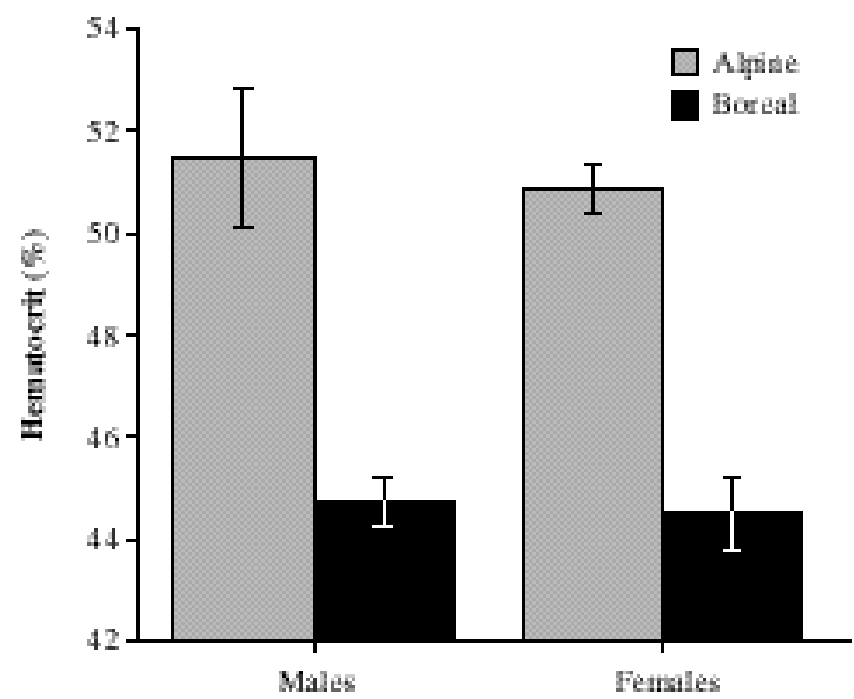

FIGURE 3. Mean levels ( $\pm \mathrm{SE}$ ) of hematocrit measured as the packed red-blood cell volume for juvenile male ( $N=4$ alpine and 10 boreal; $P<0.0003)$ and female $(N=8$ alpine and 10 boreal; $P<0.0001)$ Arctic ground squirrels from the alpine tundra and boreal forest sites. 
TABLE III. Concentration and composition of the major types of white blood cells from blood smears. Values are expressed as means \pm SE. The Mann-Whitney $U$ - and $t$-test were used for comparisons of white blood cell types and cells per field of view, respectively.

\begin{tabular}{|c|c|c|c|c|c|c|}
\hline \multirow[b]{2}{*}{$\underline{\text { Sex }}$} & \multirow[b]{2}{*}{ Site } & \multicolumn{4}{|c|}{ White blood cell type (\%) } & \multirow{2}{*}{$\begin{array}{c}\text { Cells per field } \\
\text { View }\end{array}$} \\
\hline & & Neutrophils & Lymphocytes & Monocytes & Eosinophils & \\
\hline \multicolumn{7}{|c|}{ MALES } \\
\hline & Alpine & $63.8 \pm 0.8$ & $35.2 \pm 1.0$ & $1.0 \pm 0.7$ & $0.0 \pm 0.0$ & $1.0 \pm 0.2$ \\
\hline & Boreal & $64.3 \pm 0.9$ & $33.8 \pm 1.0$ & $1.2 \pm 0.4$ & $0.7 \pm 0.3$ & $1.1 \pm 0.2$ \\
\hline \multicolumn{7}{|c|}{ FEMALES } \\
\hline & Alpine & $63.6 \pm 0.5$ & $34.9 \pm 0.5$ & $1.2 \pm 0.3$ & $0.2 \pm 0.2$ & $1.5 \pm 0.1 * *$ \\
\hline & Boreal & $64.7 \pm 1.1$ & $32.9 \pm 0.9$ & $1.3 \pm 0.4$ & $1.1 \pm 0.4$ & $0.8 \pm 0.1 * *$ \\
\hline
\end{tabular}

$* * P<0.0001$

free cortisol levels falling to low levels following the dexamethasone injection. However, females from the boreal forest site showed dexamethasone resistance, with free cortisol levels falling by only about $50 \%$ of BASE levels and remaining three times higher at the DEX bleed than that of the alpine females (Figure 2). Alpine squirrels also showed a more rapid and more marked increase in free cortisol in response to the ACTH injection. MCBC levels were significantly higher in alpine than boreal forest squirrels, although these levels were not markedly affected by the challenge protocol (Figure 2). In contrast to free cortisol levels, glucose levels were lower in alpine than boreal forest squirrels and the pattern differed between the two sites in response to the injections (Figure 2). Finally, hematocrits were significantly higher in alpine squirrels (Figure 3), and in females, in white blood cell concentrations, than boreal forest squirrels (Table III).

These differences are consistent with the hypothesis that squirrels from the boreal forest were more chronically stressed than those from the alpine tundra. Based on our understanding of Arctic ground squirrel biology, the observed differences in predation risk between the two sites appear to account for the results. There were no significant differences in available food resources or population density that could readily account for the observed differences in stress physiology. It is true that the predation risk experienced by the boreal forest squirrels in 1995 was likely to have been much less than they would have experienced during the snowshoe hare decline in 1991 and 1992 when predators were very numerous (Boonstra et al., 1998; Hubbs \& Boonstra, 1997). Nevertheless, we think that the squirrels' perception of predation risk was likely much higher in the visually restricted boreal forest than in the open alpine habitat, especially given that our sighting index was three times higher in the forest than on the alpine tundra.

Three caveats should be mentioned before discussing our results in detail. First, the levels at the BASE bleed were from animals that were already stressed by the effects of trapping and handling. From a previous study (Boonstra et al., 2001) in which we compared cortisol levels from breeding adult ground squirrels in spring that were shot (and thus not stressed by the effects of trapping and handling) to those that were livetrapped, we found that shot animals had significantly lowered free cortisol levels (values all in $\mathrm{nM}$ - males: shot $-135.8 \pm 28.6, N=19$ versus trapped $-438.4 \pm 55.5, N=8$; females: shot $-2.7 \pm 0.5$, $N=9$ versus trapped $-91.6 \pm 12.2, N=20$ ). In the present study we did not collect any shot samples and hence do not know the true baseline levels, but we assume that the response of these juveniles would be comparable to the effects of trapping. Thus we were comparing juveniles already stressed by the effects of trapping and handling at the BASE bleed, as well as their ability to respond to the hormonal challenge. Second, for logistical reasons we tested boreal forest squirrels in 1995 and alpine squirrels in 1996. We think that it is highly unlikely that potential differences between years were responsible for the observed differences between these sites. Even though the sites are near each other in terms of distance, in terms of virtually all other relevant variables (weather and predator pressure), they are largely independent of one another. Such variables as primary productivity (as measured by our biomass estimates, Figure 1) and population density show no marked difference between sites and can thus be ruled out as likely explanations for our highly significant results, based on our understanding of ground squirrel population dynamics. Third, the predation risk experience by squirrels in the boreal forest was less in 1995 than in 1996 (C. J. Krebs et $a l$. , unpubl. data) and thus the results we obtained were conservative estimates, since both snowshoe hares and their predators were in the increase phase of the "10-year cycle" by 1996 (Stefan \& Krebs, 2001).

Animals from the boreal forest exhibited lower free cortisol concentrations relative to alpine squirrels, both as a result of the stress of trapping and handling (the BASE bleed) and following the ACTH injection. The adrenals of boreal forest squirrels may have an attenuated sensitivity to ACTH, as has been found in humans (Miller \& Tyrrell, 1995), cougars (Harlow et al., 1992) and dominant male dwarf mongooses (Creel, Creel \& Monfort, 1996) when challenged by stressors. In contrast, subordinate baboons (Sapolsky, 1983), dasyurid marsupials (McDonald et al., 1986), dominant female dwarf mongooses (Creel, Creel \& Monfort, 1996), and snowshoe hares (Boonstra et al., 1998) do not show a reduced adrenal response when challenged by stressors. Boonstra et al. (1998) argue that this does not occur because animals are adapted to the stressors that they regularly encounter in nature. Arctic ground squirrels, whose dominant habitat distribution is in open Arctic and alpine tundra, and whose adaptations suit them better for areas with low vegetation cover, are perhaps not well adapted to forested habitats and have not adjusted their physiology to meet the demands for living in this very different habitat type. Their populations in the forest cycle, in synchrony with those of the snowshoe hares and predation, drive these cycles (Krebs et al., 1995; Karels et al., 2000; Hubbs \& 
Boonstra, 1997), whereas alpine populations are apparently more stable (Carl, 1971; Green, 1977). Forest squirrels may be less well adapted to deal with the pressures many different species of predators exert and this is reflected in their stress response. An alternative hypothesis is that the reduced response of the forest squirrels is in itself adaptive in order to not overreact to stressors. However, the other physiological evidence (DEX resistance and high glucose levels) argues against this.

In females from the boreal forest, free cortisol levels showed dexamethasone resistance (Figure 2). Dexamethasone resistance is typical of animals under chronic stress as the sensitivity of the HPA negative feedback system is blunted. For example, in male dasyurid marsupials that have just finished the intense breeding season and shortly before they all die, the HPA axis is resistant to DEX injections (McDonald et al., 1986; Bradley, 1990). Subordinate baboons that are chronically stressed by the dominants are dexamethasone resistant (Sapolsky, 1983). Boonstra et al. (1998) found evidence of dexamethasone resistance in the snowshoe hare, which was associated with chronic stress during the population decline but not during the population low. The dexamethasone resistance in the boreal forest animals indicates a lack of negative feedback on the HPA, probably acting through a down regulation of the glucocorticoid receptors in the hippocampus (Brooke et al., 1994), and is an important mechanism underlying elevated glucocorticoid levels in chronically stressed animals.

In our study, both male and female alpine squirrels had higher MCBC levels than their boreal forest counterparts (Figure 2), and this is consistent with the hypothesis that the latter are more stressed than the former. Normally, there is little short-term variation in the amount of corticosteroidbinding globulin (CBG, our measure of it being MCBC), but elevated glucocorticoid levels can cause CBG levels to fall (Levin et al., 1987), thus increasing free glucocorticoid levels. The depressed MCBC levels seen in the boreal forest squirrels indicate that they were less buffered from the potentially harmful effects of unbound cortisol than were the alpine squirrels. However, our handling and trapping stress and our challenge protocol resulted in lower cortisol levels in the boreal forest animals. However, both of these measures were acute stressors, and not a chronic stressor such as is likely to occur from continuous exposure to higher predation risk.

Glucose levels were much higher in both males and females from the boreal forest than alpine squirrels, both at the BASE bleed and especially in response to the DEX injection (Figure 2, Table II), but the decline with the ACTH injection in boreal forest animals makes the interpretation somewhat unclear. Acute stress such as trapping and handling should cause the release of glucose stores from the liver (Sapolsky, 1992) and the fact that boreal forest animals have significantly more of it than alpine animals (Figure 2) must mean they have larger liver glycogen stores. This is then corroborated by the DEX injection, which results in still higher levels in boreal forest animals. Both DEX and ACTH are known to mobilize glucose from liver glycogen reserves (Dallman et al., 1989). However, the decline with the ACTH injection may mean that these squirrels have reached their limit of glycogenolysis and are then into a more steady state production of glucose (such as the alpine animals appear to be doing over their entire hormone challenge) from a variety of body sources such as protein and fats. The larger glycogen stores in the boreal forest animals, which sustained the high glucose levels at the BASE and DEX bleeds, are consistent with the explanation that they were more chronically stressed. Chronically elevated levels of cortisol caused by stress promote gluconeogenesis, thus increasing the production and storage of glucose in the form of glycogen in the liver (Miller \& Tyrrell, 1995). Snowshoe hares under intense predation pressure exhibited high capacity to mobilize glucose during the decline but not during the low when predation pressure was light (Boonstra et al., 1998).

Hematocrit levels were significantly higher in alpine than in boreal forest squirrels in both sexes (Figure 3; a difference of $6 \%$ ) and this could be the consequence of two factors. First, differences in hematocrit may be a reflection of differences in altitude. Animals living at higher altitudes adapt to the lower oxygen pressure in the air by increasing their production of red blood cells and the amount of hemoglobin (hence, higher values for hematocrit) and by a change in the physicochemical properties of the hemoglobin molecule, enabling it to take in and unload oxygen more readily (Hock, 1970; Marshall \& Matthias, 1971; Monge \& Whittembury, 1974). The elevation differences between our two sites were relatively modest (most alpine squirrels were obtained from the $1700 \mathrm{~m}$ level and thus this site was only about $900 \mathrm{~m}$ higher than the boreal forest site). Both of our sites were lower than those of Marshall and Matthias (1971) who report that deermice living at $1832 \mathrm{~m}$ had hematocrits of $47.6 \%$ and those living at $2564 \mathrm{~m}$ were at $51 \%$. Second, differences in hematocrit may be a reflection of both nutritional condition and exposure to chronic stressors. Higher values indicative of better nutritional condition have been seen in a number of species (moose: Franzmann \& LeResche, 1978; collared peccaries: Lochmiller et al., 1986; black bears: Hellgren, Rogers \& Seal, 1993). Lower values indicative of exposure to chronic stress linked to high predation risk have been seen in snowshoe hares from the decline phase of the 10-year cycle (a difference of $6 \%$ from the decline phase to the low phase; Boonstra et al., 1998). The intense chronic stress of mating activity in male Arctic ground squirrels in spring is also associated with a $6 \%$ decline in hematocrit relative to adult nonbreeding males (Boonstra et al., 2001). Given the relatively low altitude of our alpine site and the modest difference in altitude between the sites, we think it unlikely that altitude can account for the entire difference we observed (the highest hematocrits we observed in boreal forest squirrels was $47 \%$ in adult females from a mammalian predator exclosure). It is probable that a portion of this difference was related to differences in predation risk between the sites.

Higher levels of free cortisol should act as an immunosuppressant (Munck, Guyre \& Holbrook, 1984; Kelley, 1985) and immunosuppression is associated with psychological stress (Biondi \& Zannino, 1997), such as might occur with a greater threat of predation. The net result will be lower levels of white blood cells and possibly higher 
rates of infection. Females, but not males, from the boreal forest had fewer white blood cells per field of view than alpine squirrels (Table III), but a higher proportion of eosinophils. Eosinophils are known to be associated with parasitic worm infections (Bullock \& Rosendahl, 1984) and these higher levels may be indicative of infection.

Demographic evidence on reproduction from large scale experiments in the boreal forest (the Kluane Boreal Forest Ecosystem project, in the valley beneath the alpine site) corroborate our conclusion that higher predation risk stressed Arctic ground squirrels in the boreal forest (McColl, 1998). In that study, mammalian predators were excluded from a $1-\mathrm{km}^{2}$ area and ground squirrel populations were live-trapped both within the exclosure and on control sites (Boonstra et al., unpubl. data). Litter sizes were greater on the predator exclosure than on the controls in four of the five years of the study $($ mean $=$ control grids: $2.6 \pm 0.6$ young per litter versus predator exclosure $3.4 \pm 0.4$ ) and more females weaned young within the predator exclosure $($ mean $=72 \%)$ than on the control grids $(45 \%)$. In some species, the indirect effects of predators on their prey may be more important in determining changes in population growth then the direct effect of predation. Anti-predatory behaviours (Holmes, 1984; Lima, 1998) can result in less time spent foraging (Holmes, 1991; Kieffer, 1991) or more time spent in protective habitats with poor quality forage, causing body condition to decline and fecundity to decrease (Hik, 1995). Stress induced by the presence of predators may also have repercussions on physiological condition, causing a decline in reproductive performance (Boonstra \& Singleton, 1993; Hik, 1995). Recent findings by Boonstra et al. (1998) indicated that snowshoe hares were chronically stressed and had lower reproduction during the population decline when predation risk was high and that stress physiology and reproduction did not improve until predation risk declined.

The stress response is subject to natural selection as is any feature of the biology of organisms. While it may be adaptive to show a marked response to a stressor in one environment, such a response might seriously affect the fitness of the organism in another. In some bird species, populations living in different environments may be able to modulate their adrenocortical responsiveness to stress either seasonally so that it may be less operative during reproduction, or within a population so that individuals vary in their response; these differences have ecological consequences (Wingfield, 1994). Bird populations living in stressful environments (e.g., the northern tundra where climate is unpredictable) may suppress their adrenocortical response to stress so that they can breed (Silverin, Arvidsson \& Wingfield, 1997), whereas populations of the same species living further south in more equitable environments always respond to this stress. This may be part of the explanation for our observations of the contrast between alpine tundra versus boreal forest animals. However, in this case the more predictable environment is the alpine one (these squirrels are primarily open habitat specialists, requiring vision to detect predators and conspecifics) and these animals always show a dramatic response to challenges. The less predictable and less suitable setting (given the squirrels' needs) is the boreal forest, and these squirrels show a more attenuated stress response which permits them to exist in this environment.

Our results are consistent with the hypothesis that Arctic ground squirrels living in the boreal forest are more chronically stressed than those living in alpine tundra regions, and we think that the most likely explanation for this is higher predation risk in the forest. Our findings leave unresolved two areas that would increase our insight into squirrels inhabiting these two areas. First, there should be demographic consequences such as reduced reproduction, decreased survival, and increased body weight loss resulting from the effects of chronic stress. Thus a comparative demographic study in both habitats is needed to examine whether such consequences occur. Second, since predation pressure in the boreal forest is known to vary with the snowshoe hare cycle, there should also be variation in the stress experienced by the forest squirrels ranging from low, when the predators have declined drastically following the decline of the snowshoe hares, to extreme when the predators are still at peak levels and are shifting to alternative prey (such as squirrels) when hares are starting to decline. A longitudinal study over this transition would elucidate the severity of this relationship. A similar study of alpinedwelling ground squirrel populations should show no significant changes over the same period if predation is the primary stressor.

\section{Acknowledgements}

We thank the Natural Sciences and Engineering Research Council of Canada for providing research grants to D. Hik and R. Boonstra and for the Collaborative Special Project funds. C. J. McColl was supported by a University of Toronto scholarship. Additional field support was provided by the Northern Scientific Training Program (DIAND). We thank the Arctic Institute of North America, University of Calgary, for use of the facilities at the Kluane Lake Base and G. Goggin-Michaud, D. Caufield and P. van Dishoek for assistance with field aspects of this study and S.-L. Kuo and C. Coltas for help with counting the white blood cells. All procedures were approved by the Animal Care Committee at the University of Toronto. This is contribution number 128 of the Kluane Boreal Forest Ecosystem Project.

\section{Literature cited}

Andrewartha, H. G. \& L. C. Birch, 1954. The Distribution and Abundance of Animals. University of Chicago Press, Chicago, Illinois.

Arenz, C. L. \& D. W. Leger, 1997. Artificial visual obstruction, antipredator vigilance, and predator detection in the thirteenlined ground squirrel (Spermophilus tridecemlineatus). Behaviour, 134: 1101-1114.

Armario, A., M. Giralt, O. Marti, A. Gavalda, J. Hidalgo, B. R. S. Hsu \& R. W. Kuhn, 1994. The effect of acute and chronic ACTH administration on pituitary-adrenal response to acute immobilization stress: Relationship to changes in corticosteroid-binding globulin. Endocrine Research, 20: 139-149.

Astheimer, L. B., W. A. Buttener \& J. C. Wingfield, 1994. Gender and seasonal differences in the adrenocortical response to ACTH challenge in an arctic passerine, Zonotrichia leucophrys gambilii. General and Comparative Endocrinology, 94: 33-43. 
Banfield, A. W. F., 1974. The Mammals of Canada. National Museum of Canada and University of Toronto Press, Toronto, Ontario.

Batzli, G. O. \& S. T. Sobaski, 1980. Distribution, abundance, and foraging patterns of ground squirrels near Atkasook, Alaska. Arctic and Alpine Research, 12: 501-510.

Biondi, M. \& L.-G. Zannino, 1997. Psychological stress, neuroimmunomodulation, and susceptibility to infectious-diseases in animals and man: A review.Psychotherapy and Psychosomatics, 66: $3-26$.

Boonstra, R., D. S. Hik, G. R. Singleton \& A. Tinnikov, 1998. The impact of predator-induced stress on the snowshoe hare cycle. Ecological Monographs, 68: 371-394.

Boonstra, R. \& C. J. McColl, 2000. Contrasting stress response of male Arctic ground squirrels and red squirrels. Journal of Experimental Zoology, 286: 390-404.

Boonstra, R., C. J. McColl \& T. J. Karels, 2001. Reproduction at all costs: How breeding compromises the stress response and survival in male Arctic ground squirrels. Ecology, 82: 1930-1946.

Boonstra, R., A. H. Hubbs, E. A. Lacey \& C. J. McColl, 2001. Seasonal changes in glucocorticoid and testosterone concentrations in free-living arctic ground squirrels from the boreal forest of the Yukon. Canadian Journal of Zoology, 79:49-58.

Boonstra, R. \& G. R. Singleton, 1993. Population declines in the snowshoe hare and the role of stress. General and Comparative Endocrinology, 91: 126-143.

Boutin, S., 1995. Testing predator-prey theory by studying fluctuation populations of small mammals. Wildlife Research, 22: 89-100

Boutin, S., C. J. Krebs, R. Boonstra, M. R. T. Dale, S. J. Hannon, K. Martin, A. R. E. Sinclair, J. N. M. Smith, R. Turkington, M. Blower, A. Byrom, F. I. Doyle, C. Doyle, D. Hik, L. Hofer, A. Hubbs, T. Karels, D. L. Murray, V. Nams, M. O'Donoghue, C. Rohner \& S. Schweiger, 1995. Population changes of the vertebrate community during a snowshoe hare cycle in Canada's boreal forest. Oikos, 74: 69-80.

Bradley, A., 1990. Failure of glucocorticoid feedback during breeding in the male red-tailed phascogale Phascogale calura (Marsupialia: Dasyuridae). Journal of Steroid Biochemistry and Molecular Biology, 37: 155-163.

Brooke, S. M., A. M. de Haas-Johnson, J. R. Kaplan, S. B. Manuck \& R. M. Sapolsky, 1994. Dexamethasone resistance among nonhuman primates associated with a selective decrease of glucocorticoid receptors in the hippocampus and a history of social instability. Neuroendocrinology, 60: 134-140.

Bullock, B. L. \& P. P. Rosendahl, 1984. Pathophysiology. Little, Brown and Co., Boston, Massachussets.

Byrom, A. E., T. Karels, C.J. Krebs \& R. Boonstra, 2000. Experimental manipulation of predation and food for Arctic ground squirrels in the boreal forest. Canadian Journal of Zoology, 78: 1309-1319.

Carl, E. A., 1971. Population control in arctic ground squirrels. Ecology, 52: 395-413.

Creel, S., N. M. Creel \& S. L. Monfort, 1996. Social stress and dominance. Nature, 379: 212.

Dallman, M. F., N. Levin, C. S. Cascio, S. F. Akana, L. Jacobson, \& R. W. Kuhn, 1989. Pharmacological evidence that the inhibition of diurnal adrenocorticotropin secretion by corticosteroids is mediated by type I corticosterone-preferring receptors. Endocrinology, 124: 2844-2850.

Dallman, M. F., S. F. Akana, C. S. Cascio, D. N. Darlington, L. Jacobson \& N. Levin, 1990. Regulation of ACTH secretion: Variations on a theme of B. Recent Progress in Hormone Research, 43: 113-173.
Day, R. W. \& G. P. Quinn, 1989. Comparisons of treatment after an analysis of variance in ecology. Ecological Monographs, 59: 433-463.

Doyle, F. I. \& J. N. M. Smith, 1994. Population responses of northern goshawks to the 10-year cycle in number of snowshoe hares. Studies in Avian Biology, 16: 122-129.

Fleshner, M., T. Deak, R. L. Spencer, M. L. Laudenslager, L. R. Watkins \& S. F. Maier, 1995. A long term increase in basal levels of corticosterone and a decrease in corticosteroid-binding globulin after acute stressor exposure. Endocrinology, 136: 5336-5342.

Franzmann, A. W. \& R. E. LeResche, 1978. Alaskan moose blood studies with emphasis on condition evaluation. Journal of Wildlife Management, 42: 334-351.

Gagnon, J., J. Roth, B. Finzer, R. Hofmann, K. Haycock, J. Simpson \& D. Feldman, 1990. SuperANOVA: Accessible General Linear Modelling. Abacus Concepts, Inc., Berkeley, California.

Green, J. E., 1977. Population regulation and annual cycles of activity and dispersal in the Arctic ground squirrel. M.Sc. thesis, University of British Columbia, Vancouver, British Columbia.

Harlow, H. J., F. G. Lindzey, W. D. Van Sickle \& W. A. Gern, 1992. Stress response of cougars to nonlethal pursuit by hunters. Canadian Journal of Zoology, 70: 136-139.

Hellgren, E. C., L. L. Rogers, \& U. S. Seal, 1993. Serum chemistry and hematology of black bears: Physiological indices of habitat quality or seasonal patterns. Journal of Mammalogy, 74: 304-315.

Hik, D. S., 1995. Does risk of predation influence population dynamics? Evidence from the cyclic decline of snowshoe hares. Wildlife Research, 22: 115-129.

Hochachka, W. M., K. Martin, F. Doyle and C. J. Krebs, 2000. Monitoring vertebrate populations using observational data. Canadian Journal of Zoology, 78: 521-529.

Hock, R. J., 1970. The physiology of high altitude. Scientific American, 22: 52-62.

Holmes, W. G., 1984. Predation risk and foraging behavior of the hoary marmot in Alaska. Behavioural Ecology and Sociobiology, 15: 293-301.

Holmes, W. G., 1991. Predator risk affects foraging behaviour of pikas: Observational and experimental evidence. Animal Behaviour, 42: 111-119.

Hubbs, A. H. \& R. Boonstra, 1997. Population limitation in Arctic ground squirrels: Effects of food and predation. Journal of Animal Ecology, 66: 527-541.

Hubbs, A. H., T. Karels \& A. Byrom, 1996. Tree-climbing by Arctic Ground Squirrels, Spermophilus parryii, in the southwestern Yukon Territory. Canadian Field-Naturalist, 110: 533-534.

Kalin, N. H., R. M. Cohen, G. W. Kraemer, S. C. Risch, S. Shelton, M. Cohen, W. T. McKinney \& D. L. Murphy, 1981. The dexamethasone suppression test as a measure of hypothalamicpituitary feedback sensitivity and its relationship to behavioral arousal. Neuroendocrinology, 32: 92-95.

Karels, T. J. \& R. Boonstra, 1999. The impact of predation on burrow use by Arctic ground squirrels in the boreal forest. Proceedings of the Royal Society (London), 266: 2117-2123.

Karels, T. J., A. Byrom, R. Boonstra \& C. J. Krebs, 2000. The interactive effects of food and predators on reproduction and overwinter survival of Arctic ground squirrels. Journal of Animal Ecology, 69: 235-247.

Keller, S. E., S. J. Schleifer \& M. Stein, 1984. Stress-induced suppression of lymphocyte function in rats. Pages 10-121 in E. L. Cooper (ed.). Stress, Immunity, and Aging. Marcel Dekker, New York. 
Kelley, K. W., 1985. Immunological consequences of changing environmental stimuli. Pages 193-223 in G. P. Moberg (ed.). Animal Stress. American Physiological Society. Baltimore, Maryland.

Keppel, G., 1982. Design and Analysis: A Researcher's Handbook. Second edition. Prentice-Hall, Englewood Cliffs, New Jersey.

Kieffer, J. D., 1991. The influence of apparent predation risk on the foraging behaviour of eastern chipmunks (Tamias striatus). Canadian Journal of Zoology, 69: 2349-2351.

Krebs, C. J., S. Boutin, R. Boonstra, A. R. E. Sinclair, J. N. M. Smith, M. R. T. Dale, K. Martin \& R. Turkington, 1995. Impact of food and predation on the snowshoe hare cycle. Science, 269: 1112-1115.

Krebs, C. J., A. R. E. Sinclair, R. Boonstra, S. Boutin, K. Martin \& J. N. M. Smith, 1998. Community dynamics of vertebrate herbivores: How can we untangle the web? Pages 447-473 in H. Olff, V. K. Brown, \& R. H. Drent (ed.). Herbivores: Between Plants and Predators. Blackwell Scientific Publications, Oxford.

Krebs, C. J., S. Boutin \& Boonstra (ed.), 2001. Ecosystem Dynamics of the Boreal Forest: The Kluane Project. Oxford University Press, New York.

Lacey, E. A., 1991. Reproductive and dispersal strategies of male Arctic ground squirrels (Spermophilus parryii plesius). Ph.D. Thesis, University of Michigan, Ann Arbor, Michigan.

Lee, A. K. \& I. R. McDonald, 1985. Stress and population regulation in small mammals. Oxford Reviews in Reproductive Biology, 7: 261-304.

Levin, N., S. F. Akana, L. Jacobson, R. W. Kuhn, P. K. Siiteri \& M. F. Dallman, 1987. Plasma adrenocorticotropin is more sensitive than transcortin production or thymus weight to inhibition by corticosterone in rats. Endocrinology, 121: 1104-1110.

Levine, S., C. Coe \& S. G. Wiener, 1989. Psychoneuroendocrinology of stress: A psychobiological perspective. Pages 341377 in F. R. Brush \& S. Levine (ed.). Psychoendocrinology. Academic Press, San Diego, California.

Lima, S. L., 1998. Nonlethal effects in the ecology of predatorprey interactions. BioScience, 48: 25-34.

Lima, S. L. \& L. M. Dill, 1990. Behavioral decisions made under the risk of predation: A review and prospectus. Canadian Journal of Zoology, 68: 619-640.

Lochmiller, R. L., E. C. Hellgren, L. W. Varner \& W. E. Grant, 1986. Serum and urine biochemical indicators of nutritional status in adult female collared peccaries, Tayassu tajacu (Tayassuidae). Comparative Biochemistry and Physiology, 83: 477-488.

MacHutchon, A. G. \& A. S. Harestad, 1990. Vigilance behaviour and use of rocks by Columbian ground squirrels. Canadian Journal of Zoology, 68: 1428-1432.

Marshal, L. G. \& D. V. Matthias, 1971. Correlations between physiological parameters of blood and altitude in Peromyscus maniculatus. Journal of Mammalogy, 52: 449-450.

Mason, J., 1968. A review of psychoendocrine research on the pituitary-adrenal cortical system. Psychomatic Medicine, 30: 576-607.

McColl, C. J., 1998. The role of food, predation, and population density on the stress physiology of Arctic ground squirrels. M.Sc. thesis, University of Toronto, Toronto, Ontario.

McColl, C. J. \& R. Boonstra, 1999. The physiological effects of three inhalant anesthetics on Arctic ground squirrels. Wildlife Society Bulletin, 27: 946-951.

McDonald, I. R., A. K. Lee, A. J. Bradley \& K. A. Than, 1981. Endocrine changes in dasyurid marsupials with differing mortality patterns. General and Comparative Endocrinology, 44: 292-301.
McDonald, I. R., A. K. Lee, K. A. Than, \& R. W. Martin, 1986. Failure of glucocorticoid feedback in males of a population of small marsupials (Antechinus swainsonii) during a period of mating. Journal of Endocrinology, 108: 63-68.

McIntire, E. J. B., 1999. The effects of collared pika grazing on alpine tundra vegetation in southwestern Yukon, Canada. M.Sc. Thesis, University of Toronto, Toronto, Ontario.

McLean, I. G., 1981. Social ecology of the Arctic ground squirrel Spermophilus parryii. Ph.D. Thesis, University of Alberta, Edmonton, Alberta.

Menkens, G. E. \& S. H. Anderson, 1988. Estimation of smallmammal population size. Ecology, 69: 1952-1959

Miller, W. L. \& J. B. Tyrrell, 1995. The adrenal cortex. Pages 555-711 in P. Felig, J. D. Baxter, \& L. A. Frohman (ed.). Endocrinology and Metabolism. Third edition, McGraw-Hill, New York.

Monge, C. \& J. Whittembury, 1974. Increased hemoglobin-oxygen affinity at extremely high altitudes. Science, 186: 843.

Munck, A., P. Guyre \& N. Holbrook, 1984. Physiological functions of glucocorticoids during stress and their relation to pharmacological actions. Endocrine Reviews, 5: 25-44.

Murdoch, W. W., 1994. Population regulation in theory and practice. Ecology, 75: 271-287.

O'Donoghue, M., S. Boutin, C. J. Krebs, G. Zuleta, D. L. Murray \& E. J. Hofer, 1998. Functional-responses of coyotes and lynx to the snowshoe hare cycle. Ecology, 79: 1193-1208.

Parker, E. D., V. E. Forbes, S. L. Nielsen, C. Ritter, C. Barata, D. J. Baird, W. Admiraal, L. Levin, V. Loeschke, P. LyytikäinenSaarenmaa, J. Høgh-Jensen, P. Calow \& B. J. Ripley, 1999. Stress in ecological systems. Oikos, 86: 179-184.

Peters, T., Jr., 1996. All About Albumin. Academic Press, San Diego, California.

Rosner, W., 1990. The functions of corticosteroid-binding globulin and sex hormone-binding globulin: Recent advances. Endocrine Reviews, 11: 80-91.

Sandberg, A. A. \& W. R. Slaunwhite, Jr., 1959. Transcortin: A corticosteroid-binding protein of plasma. II. Levels in various conditions and the effects of estrogens. Journal of Chemical Investigations, 38: 1290-1297.

Sapolsky, R., 1983. Individual differences in cortisol secretory patterns in the wild baboon: Role of negative feedback sensitivity. Endocrinology, 113: 2263-2267.

Sapolsky, R., 1992. Neuroendocrinology of the stress-response. Pages 287-324 in J. B. Becker, S. M. Breedlove, \& D. Crews (ed.). Behavioral Endocrinology. MIT Press, Cambridge, Massachussets.

Schooley, R. L., P. B. Sharpe \& B. Van Horne, 1996. Can shrub cover increase predation risk for a desert rodent. Canadian Journal of Zoology, 74: 157-163.

Siiteri, P. K, J. T. Murai, G. L. Hammond, J. A. Nisker, W. J. Raymoure \& R. W. Kuhn, 1982. The serum transport of steroid hormones. Recent Progress in Hormone Research, 38: 457-510.

Silverin, B., B. Arvidsson \& J. C. Wingfield, 1997. The adrenocortical responses to stress in breeding willow warblers Phylloscopus trochilus in Sweden: Effects of latitude and gender. Functional Ecology, 11: 376-384.

Sinclair, A. R. E. \& R. P. Pech, 1996. Density dependence, stochasticity, compensation and predator regulation. Oikos, 75: 164-173.

Smith, J. H. \& G. A. Bubenik, 1990. Plasma concentrations of glucocorticoids in white-tailed deer: The effect of acute ACTH and dexamethasone administration. Canadian Journal of Zoology, 68: 2123-2129.

Stefan, C. I. \& C. J. Krebs. 2001. Reproductive changes in a cyclic population of snowshoe hares. Canadian Journal of Zoology 79: in press. 
Tait, J. R. S. \& S. Burstein, 1964. In vivo studies of steroid dynamics in man. Pages 441-557 in G. Pincus, K. V. Thinman, \& E. B. Astwood (ed.). The Hormones, Volume 5. Academic Press, New York.

Thorson, J. M., R. A. Morgan, J. S. Brown \& J. E. Norman, 1998. Direct and indirect cues of predatory risk and patch use by fox squirrels and thirteen-lined ground squirrels. Behavioural Ecology, 9: 151-157. van Disheock, P., 1997. Ecology of alpine dwelling Arctic ground squirrels in the southwest Yukon. B.Sc. thesis, University of British Columbia, Vancouver, British Columbia.

Winer, B. J., 1971. Statistical principles in experimental design. Second edition. McGraw-Hill, New York.

Wingfield, J. C., 1994. Modulation of the adrenocortical response to stress in birds. Pages 520-528 in K. G. Davey, R. E. Peter \& S. S. Tobe (ed.). Perspectives in Comparative Endocrinology. National Research Council of Canada, Ottawa, Ontario. 